\title{
MicroRNA-182 Regulates Amygdala-Dependent Memory Formation
}

\author{
Erica M. Griggs, ${ }^{1,2}$ Erica J. Young, ${ }^{1,2}$ Gavin Rumbaugh, ${ }^{2}$ and Courtney A. Miller ${ }^{1,2}$ \\ ${ }^{1}$ Department of Metabolism and Aging, and ${ }^{2}$ Department of Neuroscience, The Scripps Research Institute, Jupiter, Florida 33477
}

\begin{abstract}
De novo protein synthesis supports long-lasting functional and structural plasticity and is a molecular requirement for new memory formation. Recent evidence has suggested that microRNAs may be involved in regulating the molecular mechanisms underlying neural plasticity. MicroRNAs are endogenous, noncoding RNAs capable of post-transcriptional repression of their mRNA targets. To explore the potential for microRNA-mediated regulation of amygdala-dependent memory formation, we performed expression profiling of microRNAs in the lateral amygdala of rats $1 \mathrm{~h}$ after auditory fear conditioning. Microarray analysis revealed that over half of all known microRNAs are endogenously expressed in the lateral amygdala, with 7 microRNAs upregulated and 32 downregulated by auditory fear training. Bioinformatic analysis identified several of the downregulated microRNAs as potential repressors of actin-regulating proteins known to be involved in plasticity and memory. Downregulation of one of these microRNAs by auditory fear conditioning, miR-182, was confirmed by quantitative real-time PCR. Overexpression of miR-182 within the lateral amygdala resulted in decreased expression of the protein but not mRNA of two synapse-enriched regulators of actin known to modulate structural plasticity, cortactin and Racl. The overexpression of miR-182 also disrupted long-term but not short-term auditory fear memory. These data indicate that learning-induced suppression of miR-182, a microRNA previously uncharacterized in the brain, supports long-term memory formation in the amygdala and suggests it does so, at least in part, through the derepression of key actin-regulating proteins. These findings further indicate that microRNAs may represent a previously underappreciated mechanism for regulating protein synthesis during memory consolidation.
\end{abstract}

\section{Introduction}

Long-term memory formation requires new protein synthesis (Davis and Squire, 1984; McGaugh, 2000). MicroRNAs (miRNAs), endogenous RNAs that act as translational repressors, represent a potential mechanism for regulating the complex translational program supporting memory. MiRNAs achieve post-transcriptional repression by direct binding to the $3^{\prime}$-UTR of target mRNAs and noncleavage degradation of the target mRNA via deadenylation (Lim et al., 2005; Giraldez et al., 2006; Eulalio et al., 2009; Djuranovic et al., 2012). A single miRNA commonly has hundreds of predicted targets based on 2-8 nucleotide (nt) seed region complementarity, with actual targets likely to vary depending on the structure and even cell type being studied. This flexibility and wide-genomic range suggests that these short $(\sim 22 \mathrm{nt})$, noncoding RNAs are perfectly suited to orchestrate complex post-transcriptional programs tailored to the particular needs of any given system. In the case of learning and memory processes, some of the earliest evidence of miRNA

Received June 16, 2012; revised Nov. 5, 2012; accepted Dec. 5, 2012.

Author contributions: E.M.G. and C.A.M. designed research; E.M.G. and E.J.Y. performed research; E.M.G., G.R., and C.A.M. analyzed data; E.M.G. and C.A.M. wrote the paper.

This work was supported by NIH/NIDA Grant R00DA024761 (to C.A.M.) and NIH/NINDS Grant R01NS064079 (to G.R.). We thank A. Faruzzi-Brantley, as well as B. Young, B. Long, and S. Willis of the TSRI Behavior and Genomics Cores for their assistance.

The authors declare no competing financial interests.

Correspondence should be addressed to Courtney A. Miller, 130 Scripps Way, Jupiter, FL 33466. E-mail: cmiller@scripps.edu, 130 Scripps Way, Jupiter, FL 33477.

DOI:10.1523/JNEUROSCI.2873-12.2013

Copyright $\odot 2013$ the authors $\quad 0270-6474 / 13 / 331734-07 \$ 15.00 / 0$ involvement came from studies in Drosophila that demonstrated learning-induced degradation of Armitage, a critical component of the miRNA-induced silencing complex (RISC), at synapses, and its loss enhances memory (Ashraf and Kunes, 2006; Konopka et al., 2010). Global reduction in miRNA expression within the rodent forebrain also produces memory enhancement and several miRNAs have been identified in the hippocampus and cortex as regulators of memory (Schratt et al., 2006; Gao et al., 2010; Konopka et al., 2010; Kye et al., 2011; Lin et al., 2011; Zovoilis et al., 2011).

There is also a growing consensus that memory is supported by structural and functional plasticity at excitatory synapses on dendritic spines (Pontrello and Ethell, 2009; Kasai et al., 2010). Several miRNAs have been implicated in the regulation of synaptogenesis and morphology in development (Schratt et al., 2006; Yu et al., 2008; Fiore et al., 2009; Siegel et al., 2009; Edbauer et al., 2010). Brain-specific miR-134, for example, is enriched in the synaptodendritic compartment of cultured hippocampal neurons, where it prevents translation of LIMK1, a kinase that leads to the phosphorylation and inactivation of the actin-severing protein cofilin and regulates spine size in developing neurons (Schratt et al., 2006). Actin is the major cytoskeletal component of dendritic spines, and its polymerization is required for synaptic plasticity and memory formation (Fischer et al., 2004; Mantzur et al., 2009; Rehberg et al., 2010; Rex et al., 2010; Gavin et al., 2012). Actin is under tight spatiotemporal control by a multitude of actin regulatory proteins (ARPs). Cofilin, for example, supports cytoskeletal rearrangement. Loss of cofilin results in memory impairment and a reduction in the number of mature dendritic spines (Hotulainen et al., 2009; Rust et al., 2010). A 
conservative estimate would put the number of direct actinbinding proteins expressed in the CNS in the dozens, with a multitude of additional upstream regulators. Taken together, this suggests that the CNS may use miRNAs to achieve strict regulatory control over the expression of ARPs during memory formation. Because the amygdala plays a critical role in many forms of cognition, including psychiatric disorders with a memory component (Childress et al., 1999; Koenigs and Grafman, 2009), we explored the hypothesis that consolidation of an amygdaladependent memory is influenced by miRNAs, possibly through the post-transcriptional regulation of ARPs.

\section{Materials and Methods}

Animals. Male Sprague Dawley rats (275-325 g; Charles River Laboratories) were housed individually following cannula implantation on a $12 \mathrm{~h}$ light/dark cycle at ambient temperature with food and water ad libitum. All animal procedures were conducted in accordance with the NIH Guide for the Care and Use of Laboratory Animals and with protocols approved by the Scripps Florida Institutional Animal Care and Use Committee.
Cannula implantation. Rats were anesthetized with Dexdormitor $(0.25$ $\mathrm{mg} / \mathrm{kg}$ ) and Ketamine $(5 \mathrm{mg} / 100 \mathrm{~g})$ and secured in a Kopf stereotaxic apparatus. Bilateral stainless steel guide cannula (26 G, Plastics One) were placed directly above the lateral amygdala (LA) (anteroposterior, $-3.0 \mathrm{~mm}$, mediolateral, $-5.0 \mathrm{~mm}$, relative to bregma; dorsoventral, $-6.5 \mathrm{~mm}$ from skull) (Paxinos and Watson, 2007). Clearance was maintained with $33 \mathrm{G}$ obdurators (Plastics One) cut to project $1 \mathrm{~mm}$ beyond the tip of the guide. Cannula placement was verified in $40 \mu \mathrm{m}$ cresyl violet-stained sections.

Auditory fear conditioning. Training and testing were performed as described previously (Gavin et al., 2012). In the same group of animals, immediate learning was assessed by the percent of time spent freezing during the second and third training tone presentations (Schafe et al., 2000), and longterm memory (LTM) was assessed $24 \mathrm{~h}$ later during the $3 \mathrm{~min}$ tone presentation that followed a $3 \mathrm{~min}$ period of exploration in the altered context. Short-term fear memory (STM) was assessed 90 min after training in a separate group of animals. LTM and STM were calculated by subtracting the freezing in the altered context from the freezing during the tone to isolate auditory fear memory from residual contextual fear.

MicroRNA overexpression. Intra-LA miRNA overexpression was achieved by in vivo transfection of an Rattus norvegicus miR-182 mimic
A

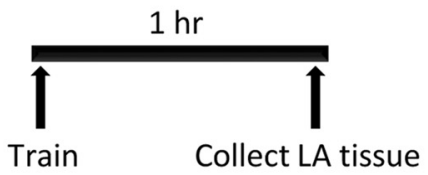

B

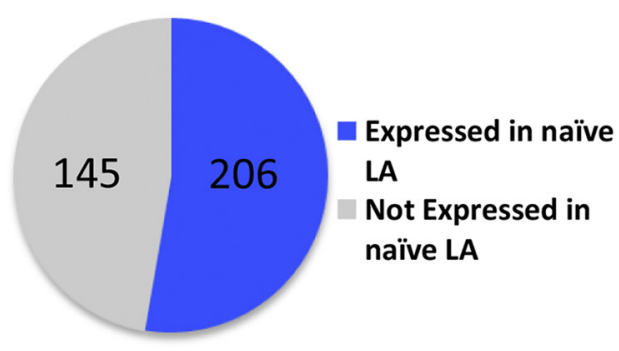

C

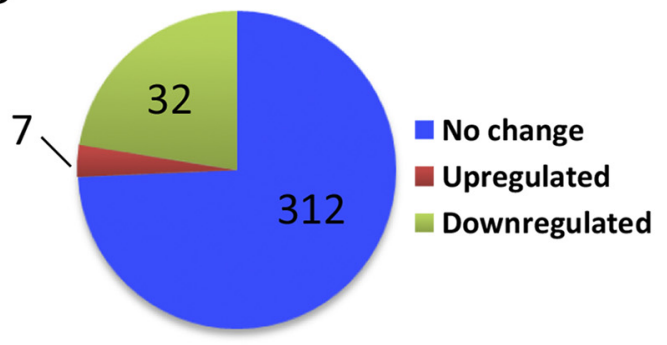

D

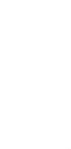

$E$
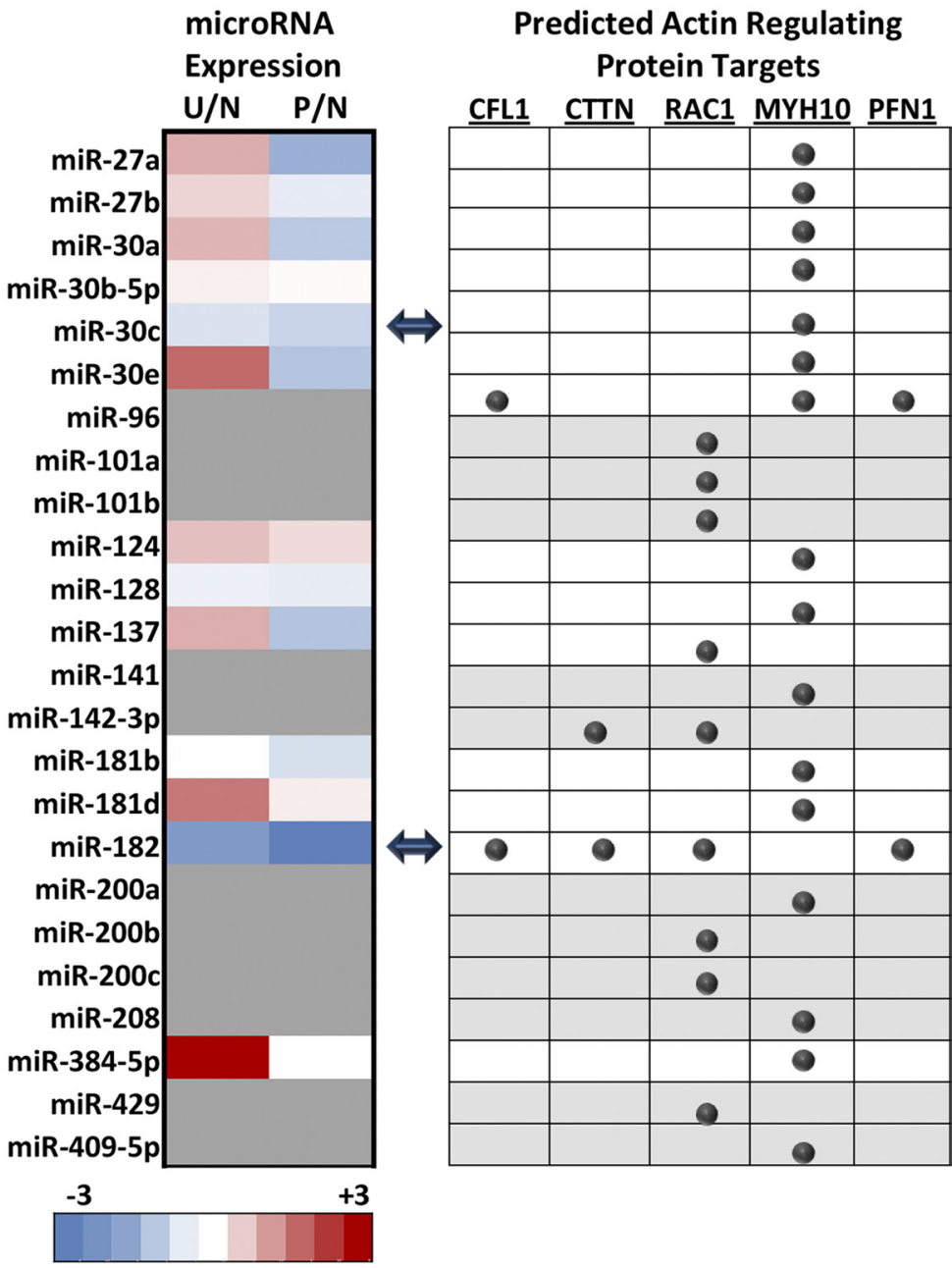

Relative expression

Not expressed

Figure 1. Auditory fear conditioning downregulates miR-182 in the LA. $\boldsymbol{A}$, Schematic of experimental design. $\boldsymbol{B}$, Representation of the miRNAs on the GeneArray Chip that are basally expressed in the LA of rats. C, Differential expression of the 206 miRNAs expressed in the LA $1 \mathrm{~h}$ after training, relative to Naive and Unpaired controls. D, $1 \mathrm{~h}$ post-training expression of miRNAs specifically predicted to have ARP targets. Color scale represents miRNA expression levels normalized to Naive. Gray shading represents miRNAs below detection in the LA. $\boldsymbol{E}$, Predicted ARP targets of each miRNA depicted in $\boldsymbol{D}$. 
(rno-miR-182OE) or a Caenorhabditis elegans miR-67 mimic negative control (cel-miR-67OE) (Dharmacon) with jetSI (PolyPlus Transfection) (Guissouma et al., 2006; McQuown et al., 2011). The negative control has minimal sequence homology to miRNA sequences in rats, mice, and humans. Both miRNA mimics were delivered into the LA at the same rate $(0.25 \mu \mathrm{l} / \mathrm{min})$, concentration $(5.6 \mu \mathrm{g})$, and volume $(0.5 \mu \mathrm{l})$.

Tissue preparation. Animals were quickly and deeply anesthetized with isoflurane. Brains were then rapidly removed, flash frozen in 2-methyl butane (Sigma), sliced into $1 \mathrm{~mm}$ thick sections, and stored at $-80^{\circ} \mathrm{C}$.

RNA and protein extraction. For quantitative RT-PCR (qRT-PCR) and immunoblotting, RNA and protein were extracted from $1 \mathrm{~mm}^{3}$ punches of LA tissue using the miRVana RNA isolation kit (Ambion). RNA concentrations and quality were determined with a Nanodrop ND-1000 (Thermo Fisher Scientific). Protein concentrations were determined by Bradford assay (Bio-Rad) with 1:10 dilutions of protein homogenate.

MicroRNA microarray. One hour after training, tissue was collected and total RNA was TRIzol-extracted from LA. One microgram of total RNA was pooled for each group such that RNA from each of the eight animals in a given group was equally represented in the appropriate pooled sample, resulting in three samples of $1 \mu \mathrm{g}$ for each array ( $n=4$ pooled arrays): paired, unpaired, and naive. The remaining individual samples of RNA were retained for validation by qRT-PCR. Gene expression analysis arrays were performed by the Scripps Florida Genomics Core. Pooled samples were labeled using the 3DNA FlashTag kit (Genisphere) and hybridized to Affymetrix miRNA microarray in the Affy 640 hybridization oven for $16 \mathrm{~h}$ at 60 rpm. The microarrays were then washed and stained with the Affymetrix Fluidics Station FS400. The GeneChip Scanner 3000 was used to scan the GeneChip Arrays. All probe set intensities were quantified using the GeneChip Command Console Software (AGCC) and analyzed with GCRMA normalization using Affymetrix Expression Console Software. All raw values below 100 were excluded from the analysis.

MiRNA cDNA synthesis and $q R T-P C R$. Quantitative real-time PCR was used to measure expression of individual miRNAs. Ten nanograms of RNA was reverse transcribed using miRNA Reverse Transcription Kit [Applied Biosystems Inc. (ABI)], and cDNA was preamplified using miRNA-specific primers (ABI). The PCR product was diluted with TaqMan Gene Expression Master Mix (ABI), and FAM TaqMan microRNA Gene Expression assays (ABI) were used to quantify levels of miRNAs with U6 snRNA as a control. All $C_{T}$ values were chosen in the linear range of amplification, and the comparative $\mathrm{C}_{\mathrm{T}}$ method was used to calculate relative differences in gene expression.

Immunoblotting. Ten micrograms of protein from LA tissue collected $4 \mathrm{~h}$ post-training was resolved on $10 \%$ SDS-PAGE gels and transferred onto PVDF membranes and then blocked in $5 \%$ milk in $0.1 \%$ Trisbuffered saline-Tween 20 (TBST) at room temperature (RT) for $1 \mathrm{~h}$. Antibodies were used against cortactin (1:50,000, Abcam), cofilin (1:500, Cytoskeleton Inc.), profilin (1:500, Cytoskeleton Inc.), Rac1 (1:750, Abcam), and GAPDH (1:5000, Abcam) for $1 \mathrm{~h}$ at RT. Membranes were washed with $1 \times$ TBST and incubated with anti-mouse (Vector Laboratories) or antirabbit (Promega) IgG horseradish peroxidase-conjugated secondary antibody (1:10,000, $1 \times$ TBST). Protein expression was assessed by enhanced chemiluminescence and exposure to Biomax Light film (Eastman Kodak). ImageJ software (NIH) was used to quantify band intensities. Relative protein expression was calculated by normalizing the integrated band density values to those for GAPDH on the same blots.

Statistical analysis. Repeated measures and one-way ANOVAs, as well as one-sample $t$ tests with Bonferroni correction were used as stated.

\section{Results \\ Auditory fear conditioning alters miR-182 expression in the lateral amygdala}

To identify the potential involvement of miRNAs in amygdaladependent memory formation, we trained animals in a traditional auditory fear conditioning paradigm (Fig. $1 A$ ). One hour after training, LA tissue was collected from three groups of animals: Naive Handled, Unpaired, and Paired. Unpaired animals were presented with the same stimuli as the Paired animals, ex-
Table 1. Twenty-five highest and lowest expressed miRNAs in LA of Naive animals

\begin{tabular}{|c|c|c|c|c|}
\hline \multirow[b]{2}{*}{ Number } & \multicolumn{2}{|l|}{ Highest } & \multicolumn{2}{|l|}{ Lowest } \\
\hline & $\operatorname{miR}$ & Intensity & $\operatorname{miR}$ & Intensity \\
\hline 1 & rno-let-7c & 80074 & rno-miR-193 & 101 \\
\hline 2 & rno-let-7b & 52551 & rno-miR-301a & 105 \\
\hline 3 & rno-let-7a & 43725 & rno-miR-184 & 108 \\
\hline 4 & rno-let-7d & 36525 & rno-miR-181a-star & 110 \\
\hline 5 & rno-miR-125b-5p & 35377 & rno-miR-412 & 115 \\
\hline 6 & rno-miR-124 & 33622 & rno-miR-377 & 116 \\
\hline 7 & rno-miR-26a & 32032 & rno-miR-30b-3p & 117 \\
\hline 8 & rno-let-7e & 31511 & rno-miR-345-3p & 117 \\
\hline 9 & rno-miR-132 & 26602 & rno-miR-671 & 118 \\
\hline 10 & rno-miR-128 & 20690 & rno-miR-339-5p & 118 \\
\hline 11 & rno-miR-125a-5p & 17875 & rno-miR-497 & 121 \\
\hline 12 & rno-miR-191 & 16906 & rno-miR-542-5p & 121 \\
\hline 13 & rno-miR-23b & 15599 & rno-miR-let-7d-star & 122 \\
\hline 14 & rno-let-7f & 13944 & rno-miR-350 & 122 \\
\hline 15 & rno-miR-103 & 12887 & rno-miR-182 & 123 \\
\hline 16 & rno-let-7i & 12646 & rno-miR-20a-star & 124 \\
\hline 17 & rno-miR-24 & 12634 & rno-miR-218-star & 124 \\
\hline 18 & rno-miR-29a & 10974 & rno-miR-142-5p & 126 \\
\hline 19 & rno-miR-138 & 10503 & rno-miR-323 & 126 \\
\hline 20 & rno-miR-107 & 9813 & rno-miR-188 & 127 \\
\hline 21 & rno-miR-127 & 8281 & rno-miR-881 & 128 \\
\hline 22 & rno-miR-23a & 8102 & rno-miR-598-5p & 131 \\
\hline 23 & rno-miR-222 & 7930 & rno-miR-743b & 134 \\
\hline 24 & rno-miR-16 & 7917 & rno-miR-379-star & 134 \\
\hline 25 & rno-miR-99b & 7249 & rno-miR-337 & 134 \\
\hline
\end{tabular}

Note miR-182's low expression levels (boldface).

cept that the shock did not coterminate with the tone, preventing the formation of a learned association between the tone and shock. Expression profiling of this tissue revealed that more than half of all known R. norvegicus miRNAs are expressed in the LA of Naive animals (Fig. 1B). Table 1 lists the 25 highest and lowest expressed miRNAs in the LA. The majority of LA-expressed miRNAs were unchanged by auditory fear training, while 7 were upregulated and 32 were downregulated relative to Naive and Unpaired controls (Fig. 1C). We chose to focus on miRNAs predicted to target at least one of several ARPs (cofilin, cortactin, $\mathrm{Rac1}, \mathrm{MyH} 10$, profilin) because of their known function in regulating the dendritic spine structural and functional plasticity that supports memory. Using TargetScan, we searched the 3' UTR of these ARPs for conserved sites for miRNAs (Fig. $1 D, E$ ). From this list of ARP-associated miRNAs we then looked for miRNAs that were specifically suppressed by auditory fear training (Paired), suggesting potential translational derepression of the ARPs. Interestingly, miR-182 was the only miRNA with predicted ARP targets (Fig. $1 D, E$ ) that decreased $>2.0$-fold in the Paired group relative to Naive group $\left(0.35 \pm 0.2, t_{(3)}=-3.15, p<0.05\right)$.

qRT-PCR of the individual samples was used to validate the array results, with miR-30c used as a negative control (no decrease expected based on array). Indeed, qRT-PCR demonstrated a decrease in miR-182, but not miR-30c, levels in the Paired group relative to Naive and Unpaired animals (Fig. 2A; miR30c: $\left.F_{(1,14)}=0.304, p>0.05 ; \mathrm{miR}-182: F_{(1,10)}=6.13, p<0.05\right)$. MiR-182 was found to be still suppressed in Paired animals $24 \mathrm{~h}$ after training (Fig. $2 B ; F_{(1,11)}=6.44, p<0.05$ ). Interestingly, while highly variable, there appeared to be a trend toward elevated miR-182 in the Unpaired group. It is possible that presentation of an auditory tone and foot shock in a noncontingent manner activates miR-182 expression to help suppress translational events intended to specifically support memory formation.

The suppression of miR-182 during memory formation was of particular interest for two reasons. First, its CNS function is 

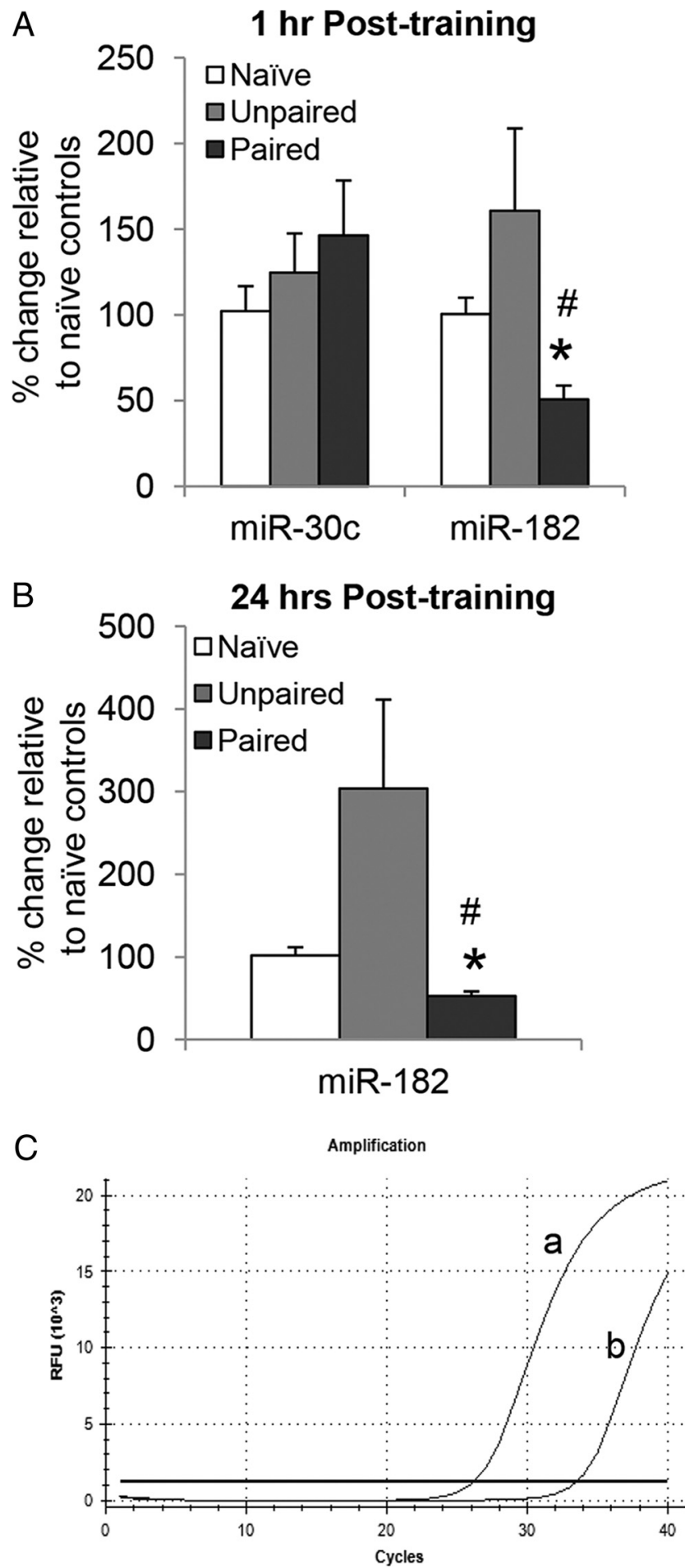

Figure 2. Auditory fear conditioning decreases miR-182 at $1 \mathrm{~h}$ and $24 \mathrm{~h}$ post-training $\boldsymbol{A}$, qRT-PCR validation of microarray results for miR-30c and miR-182 expression $1 \mathrm{~h}$ post-training, normalized to U6. Difference between Paired and Naive (\#) or Unpaired (*) animals is shown, $p<0.05$. B, qRT-PCR quantification of miR-182 levels $24 \mathrm{~h}$ post-training, normalized to U6. Difference between Paired and Naive (\#) or Unpaired (*) animals, $p<0.05$. C, Representative qRT-PCR trace of miR-30c (a) and miR-182 (b) expression levels from same Naive LA sample. Error bars represent \pm SEM.

completely unknown. Second, miR-182 is one of only two miRNAs that are predicted to target four of the five ARPs selected, miR-96 being the second (Fig. $1 E$ ). These miRNAs likely share predicted targets because they belong to the same miRNA cluster
A

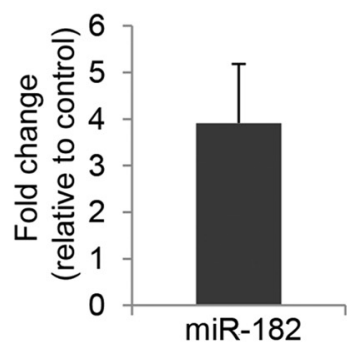

B

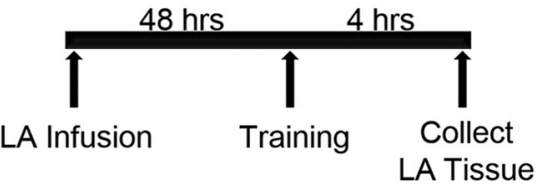

C

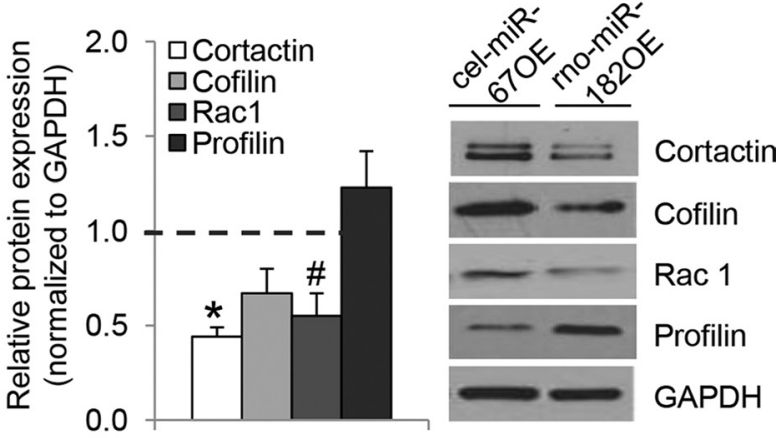

$\mathrm{D}$

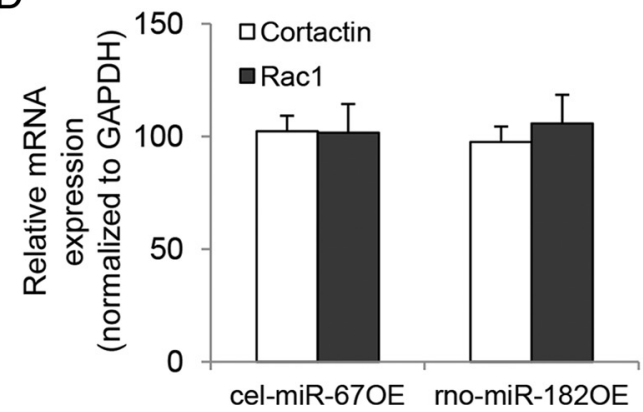

Figure 3. Overexpression of miR-182 in the LA represses cortactin and Rac1 expression following auditory fear conditioning $A$, Relative change in miR-182 levels 48 hafterintra-LA infusion of mo-miR1820 E in Naive animals, normalized to miR-182 levels in cel-miR-670E control. B, Schematic of experimental design for effect of rno-miR-1820E on ARPs.C, Western blot analysis of miR-182-predicted ARPs normalized to GAPDH and intra-LA cel-miR-670E controls (Cortactin, ${ }^{*} p<0.0005$; Rac1, ${ }^{\#} p<$ 0.01). D, qRT-PCR analysis of Cortactin and Rac1 mRNA levels, normalized to GAPDH and intra-LA cel-miR-670E controls. Error bars represent \pm SEM.

(miR-96/182/183/3553), having similar seed regions. Importantly, miR-96 is not expressed in the LA (Fig. 1D), further highlighting the potential importance of miR-182.

MiR-182 represses actin-regulating proteins and memory consolidation in the lateral amygdala

As can be seen in Table 1, miR-182 levels are very low in the LA, as compared to other miRNAs. qRT-PCR confirmed that expression of miR-182 is low in the LA, approximately $\sim 1000$-fold lower than miR-30c (Fig. 2C). Interestingly, a study that characterized enrichment of miRNAs in forebrain dendritic spines found miR-182 to be the sixth most synaptically enriched (Lugli et al., 2008), further piquing our interest in miR-182's potential regulation of synapse-rich ARPs. 
To explore miR-182's ability to regulate ARP targets in vivo, we overexpressed miR-182 (rno-miR-182OE) in the LA (Fig. $3 A$ ). We next determined the effect of miR-182 overexpression on the protein levels of its predicted ARP targets (cortactin, cofilin, Racl, and profilin) $4 \mathrm{~h}$ after auditory fear conditioning (Fig. $3 B$ ), relative to an overexpressing mimic of C. elegans miR-67 (cel-miR-67OE). Cortactin (Cttn) and Racl were decreased, with a trend toward a similar decrease in cofilin (Cfln) and no change in profilin (Pfln) (Fig. $3 C$, Cttn: $t_{(6)}=-12.13, p<0.0005$; Cfln: $t_{(6)}=-2.55, p=0.043 ; \operatorname{Rac} 1: t_{(6)}=-3.78$, $p<0.01$; Pfln: $t_{(6)}=1.19, p>0.05$; significance set at $p \leq 0.017$ with Bonferroni correction) or the housekeeping gene GAPDH (cel-miR-67OE: 1,214,892 \pm 62,242; rno-miR-182OE: 1,218,068 \pm 79,649; $\left.F_{(1,14)}=0.001, p>0.05\right)$. This suggests that the decrease in miR-182 expression accompanying auditory fear conditioning (Fig. 2A, $B$ ) removes miRNAmediated translational suppression of ARPs. Indeed, qRT-PCR analysis confirmed that mRNA levels of Cttn and Rac1 did not change (Fig. 3D; Cttn: $F_{(1,15)}=0.30, p>$ 0.05 ; Racl: $\left.F_{(1,15)}=0.08, p>0.05\right)$, suggesting that miR-182 works through post-transcriptional suppression of the ARPs, and not mRNA degradation.

Given the importance of ARPs in memory and their regulation by miR-182, we next determined the role of miR-182 in the formation of an amygdala-dependent, auditory fear memory (Fig. 4A). As the role of miR-182's ARP targets in structural and functional plasticity might predict, rno-miR-182OE disrupted freezing at the $24 \mathrm{~h}$ test, suggesting that it plays an essential role in memory formation (Fig. $\left.4 B ; F_{(1,18)}=11.93, p<0.005\right)$. Importantly, freezing to the second and third tone presentations during training was not different between the two groups (Fig. $\left.4 C ; F_{(1,14)}=0.03, p>0.05\right)$, indicating that overexpressing miR-182 did not disrupt the animals' immediate learning or ability to freeze. We next assessed STM to determine whether overexpression of miR-182 altered memory acquisition or consolidation (Rodrigues et al., 2004). STM was equivalent between the two groups at the $90 \mathrm{~min}$ post-training test (Fig. $\left.4 D, E ; F_{(1,14)}=0.27, p>0.05\right)$, indicating that rno-miR-182OE allows for the initial acquisition of an auditory fear memory, but interferes with its consolidation. Cannula placement in the LA was confirmed by histological analysis (Fig. $4 F$ ). Taken together, these results indicate that learning-induced suppression of miR-182 supports LTM formation, and that this may occur through the derepression of key remodelers of the actin cytoskeleton.
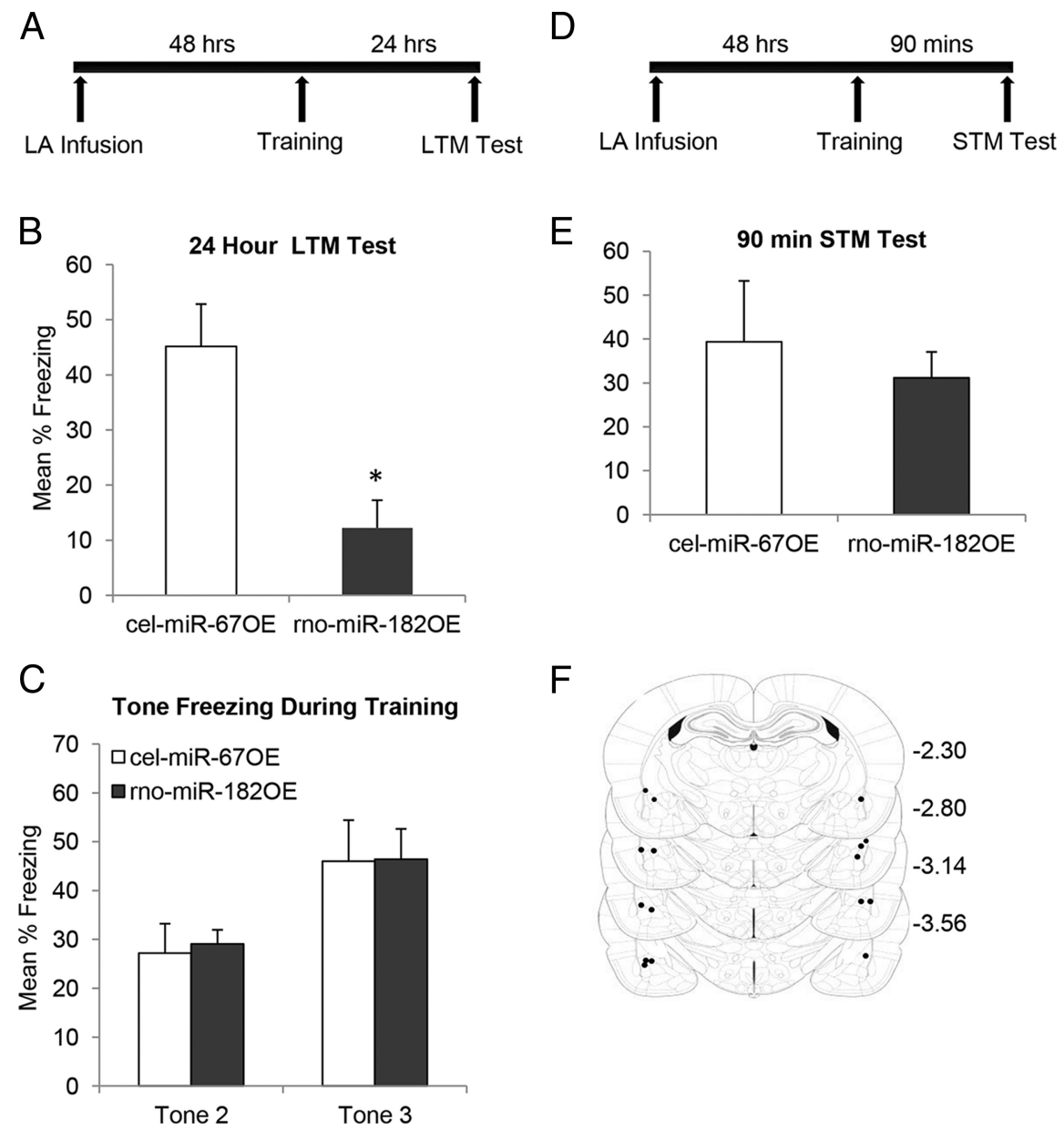

Figure 4. Overexpression of miR-182 in the LA disrupts long-term memory formation. $A$, Schematic of $L T M$ experimental design. $B, C$, Intra-LA rno-miR-1820E disrupts long-term memory formation $\left({ }^{*} p<0.005\right)(\boldsymbol{B})$ without affecting immediate learning $(\boldsymbol{C}) \boldsymbol{D}$, Schematic of STM experimental design. $\boldsymbol{E}$, Intra-LA rno-miR-1820E does not affect short-term memory formation. $\boldsymbol{F}$, Location of needle tips for intra-LA infusions. Because of overlap, not all needle tip locations are resolvable in the figure. Error bars represent \pm SEM.

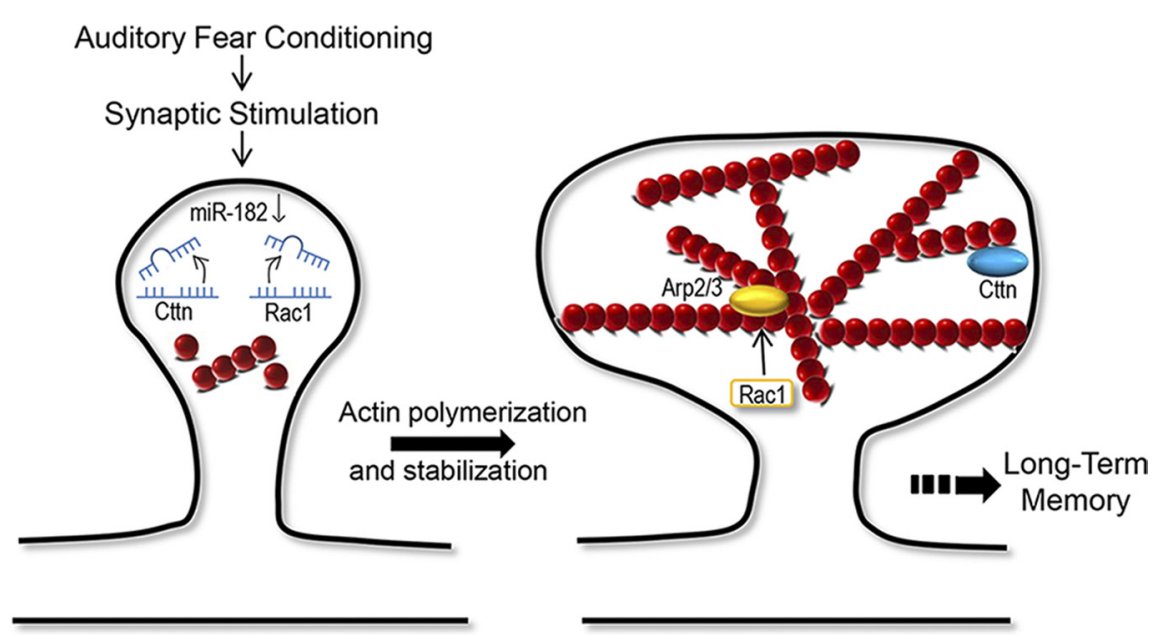

Figure 5. Proposed model of miR-182's role within the amygdala during the formation of auditory fear memory.

\section{Discussion}

This study is the first to demonstrate a role for miRNAs in amygdala-dependent memory and to describe a role for miR-182 in the brain. We were led to miR-182 by the unbiased approach of 
screening for changes in the rat genome's full complement of miRNAs following auditory fear conditioning and by our ongoing interest in actin-mediated regulation of structural plasticity in dendritic spines to support memory (Rex et al., 2010; Rubio et al., 2011; Gavin et al., 2012). Interestingly, a miR-182 knockout mouse recently generated for the purpose of studying the role of this miRNA in the retina reported no significant histological or phenotypic abnormalities in the mice (Jin et al., 2009), suggesting that miR-182 may be a viable target for cognitive therapy.

Basal expression of miR-182 is very low in the LA, with its expression reduced to nearly undetectable levels at the time of learning. Therefore, through overexpression of miR-182 in the LA, we found a disruption of memory formation and repression of two ARPs key to synaptic structure and memory, cortactin and Rac1. Knockdown of cortactin, a direct actin-binding protein that stabilizes actin filament branching, decreases dendritic spine number and maturation (Hering and Sheng, 2003; Hotulainen and Hoogenraad, 2010). Rac1 is a Rho GTPase that triggers dendritic remodeling (Diana et al., 2007; Haditsch et al., 2009; Hayashi-Takagi et al., 2010; Dietz et al., 2012) through activation of the actin-binding protein Arp2/3, driving nucleation and inactivation of cofilin to prevent depolymerization (Carlisle et al., 2008; Wegner et al., 2008). Activation of Rac1 via CNF1 enhances long-term potentiation and memory (Diana et al., 2007), while loss of Rac1 impairs both processes (Haditsch et al., 2009). Thus, derepression of cortactin and Racl via a learning-induced decrease in miR-182, as indicated here, would be expected to support memory consolidation by enabling these proteins to trigger the necessary underlying structural plasticity driven by actin polymerization (Fig. 3C and Fig. 5).

While this is the first description of miR-182's function in the brain, a few studies have investigated its role in cancerous cell growth and metastasis. Using network analysis of miR-182's predicted protein targets, one such cancer study found miR-182's top target network to be regulators of the actin cytoskeleton, including direct regulation of cofilin and profilin (Wang et al., 2012). Furthermore, a study of miR-182's role in human lung adenocarcinoma cells reported suppression of cortactin (Zhang et al., 2011). Thus, our findings on the brain's use of miR-182 to regulate memory-related structural proteins are consistent with reports of miR-182's oncogenic function.

Our findings are also consistent with the emerging hypothesis that miRNAs may contribute to the tight regulatory control of local protein synthesis needed to allow synapse-specific derepression of key memory-promoting proteins at the time of stimulation, while keeping their expression in check in times of rest (Kosik, 2006; Bicker and Schratt, 2008; Smalheiser and Lugli, 2009; Konopka et al., 2010). Smalheiser and Lugli (2009) have gone a step further by suggesting that, as part of the repressive RISC complex, miRNAs may serve a role in synaptic tagging and capture by providing synapse-specific sequestration of relevant mRNAs being trafficked down dendrites. In support of this, miRNA processing machinery has been identified in the synapse (Lugli et al., 2005), and a study by the same group established that miR-182 is the sixth most synaptically enriched miRNA in the rodent forebrain (Lugli et al., 2005; Lugli et al., 2008). Furthermore, a recent report from Cajigas et al. (2012) demonstrated that miR-182's mRNA targets are also found in the synapse, indicating that all components necessary for local translational control of ARPs by miR-182 are present in the synaptic compartment. This, in combination with our in vivo findings suggesting miR-182's regulation of cortactin, Rac1, and memory consolidation, further extends the hypothesis to suggest that a particularly important class of target proteins through which miRNAs achieve this local control may be ARPs.

\section{References}

Ashraf SI, Kunes S (2006) A trace of silence: memory and microRNA at the synapse. Curr Opin Neurobiol 16:535-539. CrossRef Medline

Bicker S, Schratt G (2008) microRNAs: tiny regulators of synapse function in development and disease. J Cell Mol Med 12:1466-1476. CrossRef Medline

Cajigas IJ, Tushev G, Will TJ, tom Dieck S, Fuerst N, Schuman EM (2012) The local transcriptome in the synaptic neuropil revealed by deep sequencing and high-resolution imaging. Neuron 74:453-466. CrossRef Medline

Carlisle HJ, Manzerra P, Marcora E, Kennedy MB (2008) SynGAP regulates steady-state and activity-dependent phosphorylation of cofilin. J Neurosci 28:13673-13683. CrossRef Medline

Childress AR, Mozley PD, McElgin W, Fitzgerald J, Reivich M, O’Brien CP (1999) Limbic activation during cue-induced cocaine craving. Am J Psychiatry 156:11-18. Medline

Davis HP, Squire LR (1984) Protein synthesis and memory: a review. Psychol Bull 96:518-559. CrossRef Medline

Diana G, Valentini G, Travaglione S, Falzano L, Pieri M, Zona C, Meschini S, Fabbri A, Fiorentini C (2007) Enhancement of learning and memory after activation of cerebral Rho GTPases. Proc Natl Acad Sci U S A 104: 636-641. CrossRef Medline

Dietz DM, Sun H, Lobo MK, Cahill ME, Chadwick B, Gao V, Koo JW, MazeiRobison MS, Dias C, Maze I, Damez-Werno D, Dietz KC, Scobie KN, Ferguson D, Christoffel D, Ohnishi Y, Hodes GE, Zheng Y, Neve RL, Hahn KM, Russo SJ, Nestler EJ (2012) Racl is essential in cocaineinduced structural plasticity of nucleus accumbens neurons. Nat Neurosci 15:891-896. CrossRef Medline

Djuranovic S, Nahvi A, Green R (2012) miRNA-mediated gene silencing by translational repression followed by mRNA deadenylation and decay. Science 336:237-240. CrossRef Medline

Edbauer D, Neilson JR, Foster KA, Wang CF, Seeburg DP, Batterton MN, Tada T, Dolan BM, Sharp PA, Sheng M (2010) Regulation of synaptic structure and function by FMRP-associated microRNAs miR-125b and miR-132. Neuron 65:373-384. CrossRef Medline

Eulalio A, Huntzinger E, Nishihara T, Rehwinkel J, Fauser M, Izaurralde E (2009) Deadenylation is a widespread effect of miRNA regulation. RNA 15:21-32. CrossRef Medline

Fiore R, Khudayberdiev S, Christensen M, Siegel G, Flavell SW, Kim TK, Greenberg ME, Schratt G (2009) Mef2-mediated transcription of the miR379-410 cluster regulates activity-dependent dendritogenesis by fine-tuning Pumilio2 protein levels. EMBO J 28:697-710. CrossRef Medline

Fischer A, Sananbenesi F, Schrick C, Spiess J, Radulovic J (2004) Distinct roles of hippocampal de novo protein synthesis and actin rearrangement in extinction of contextual fear. J Neurosci 24:1962-1966. CrossRef Medline

Gao J, Wang WY, Mao YW, Gräff J, Guan JS, Pan L, Mak G, Kim D, Su SC, Tsai LH (2010) A novel pathway regulates memory and plasticity via SIRT1 and miR-134. Nature 466:1105-1109. CrossRef Medline

Gavin CF, Rubio MD, Young E, Miller C, Rumbaugh G (2012) Myosin II motor activity in the lateral amygdala is required for fear memory consolidation. Learn Mem 19:9-14. CrossRef Medline

Giraldez AJ, Mishima Y, Rihel J, Grocock RJ, Van Dongen S, Inoue K, Enright AJ, Schier AF (2006) Zebrafish MiR-430 promotes deadenylation and clearance of maternal mRNAs. Science 312:75-79. CrossRef Medline

Guissouma H, Froidevaux MS, Hassani Z, Demeneix BA (2006) In vivo siRNA delivery to the mouse hypothalamus confirms distinct roles of TR beta isoforms in regulating TRH transcription. Neurosci Lett 406:240 243. CrossRef Medline

Haditsch U, Leone DP, Farinelli M, Chrostek-Grashoff A, Brakebusch C, Mansuy IM, McConnell SK, Palmer TD (2009) A central role for the small GTPase Rac1 in hippocampal plasticity and spatial learning and memory. Mol Cell Neurosci 41:409-419. CrossRef Medline

Hayashi-Takagi A, Takaki M, Graziane N, Seshadri S, Murdoch H, Dunlop AJ, Makino Y, Seshadri AJ, Ishizuka K, Srivastava DP, Xie Z, Baraban JM, Houslay MD, Tomoda T, Brandon NJ, Kamiya A, Yan Z, Penzes P, Sawa A (2010) Disrupted-in-Schizophrenia 1 (DISC1) regulates spines of the glutamate synapse via Rac1. Nat Neurosci 13:327-332. CrossRef Medline 
Hering H, Sheng M (2003) Activity-dependent redistribution and essential role of cortactin in dendritic spine morphogenesis. J Neurosci 23: 11759-11769. Medline

Hotulainen P, Hoogenraad CC (2010) Actin in dendritic spines: connecting dynamics to function. J Cell Biol 189:619-629. CrossRef Medline

Hotulainen P, Paunola E, Vartiainen MK, Lappalainen P (2009) Actindepolymerizing factor and cofilin-1 play overlapping roles in promoting rapid F-actin depolymerization in mammalian nonmuscle cells. Mol Biol Cell 16:649-664. CrossRef Medline

Jin ZB, Hirokawa G, Gui L, Takahashi R, Osakada F, Hiura Y, Takahashi M, Yasuhara O, Iwai N (2009) Targeted deletion of miR-182, an abundant retinal microRNA. Mol Vis 15:523-533. Medline

Kasai H, Fukuda M, Watanabe S, Hayashi-Takagi A, Noguchi J (2010) Structural dynamics of dendritic spines in memory and cognition. Trends Neurosci 33:121-129. CrossRef Medline

Koenigs M, Grafman J (2009) Posttraumatic stress disorder: the role of medial prefrontal cortex and amygdala. Neuroscientist 15:540-548. CrossRef Medline

Konopka W, Kiryk A, Novak M, Herwerth M, Parkitna JR, Wawrzyniak M, Kowarsch A, Michaluk P, Dzwonek J, Arnsperger T, Wilczynski G, Merkenschlager M, Theis FJ, Köhr G, Kaczmarek L, Schütz G (2010) MicroRNA loss enhances learning and memory in mice. J Neurosci 30: 14835-14842. CrossRef Medline

Kosik KS (2006) The neuronal microRNA system. Nat Rev Neurosci 7:911920. CrossRef Medline

Kye MJ, Neveu P, Lee YS, Zhou M, Steen JA, Sahin M, Kosik KS, Silva AJ (2011) NMDA mediated contextual conditioning changes miRNA expression. PloS One 6:e24682. CrossRef Medline

Lim LP, Lau NC, Garrett-Engele P, Grimson A, Schelter JM, Castle J, Bartel DP, Linsley PS, Johnson JM (2005) Microarray analysis shows that some microRNAs downregulate large numbers of target mRNAs. Nature 433: 769-773. CrossRef Medline

Lin Q, Wei W, Coelho CM, Li X, Baker-Andresen D, Dudley K, Ratnu VS, Boskovic Z, Kobor MS, Sun YE, Bredy TW (2011) The brain-specific microRNA miR-128b regulates the formation of fear-extinction memory. Nat Neurosci 14:1115-1117. CrossRef Medline

Lugli G, Larson J, Martone ME, Jones Y, Smalheiser NR (2005) Dicer and eIF2c are enriched at postsynaptic densities in adult mouse brain and are modified by neuronal activity in a calpain-dependent manner. J Neurochem 94:896-905. CrossRef Medline

Lugli G, Torvik VI, Larson J, Smalheiser NR (2008) Expression of microRNAs and their precursors in synaptic fractions of adult mouse forebrain. J Neurochem 106:650-661. CrossRef Medline

Mantzur L, Joels G, Lamprecht R (2009) Actin polymerization in lateral amygdala is essential for fear memory formation. Neurobiol Learn Mem 91:85-88. CrossRef Medline

McGaugh JL (2000) Memory-a century of consolidation. Science 287: 248-251. CrossRef Medline

McQuown SC, Barrett RM, Matheos DP, Post RJ, Rogge GA, Alenghat T, Mullican SE, Jones S, Rusche JR, Lazar MA, Wood MA (2011) HDAC3 is a critical negative regulator of long-term memory formation. J Neurosci 31:764-774. CrossRef Medline

Paxinos G, Watson C (2007) The rat brain in stereotaxic coordinates, Ed 6. San Diego: Elsevier.
Pontrello CG, Ethell IM (2009) Accelerators, brakes, and gears of actin dynamics in dendritic spines. Open Neurosci J 3:67-86. CrossRef Medline

Rehberg K, Bergado-Acosta JR, Koch JC, Stork O (2010) Disruption of fear memory consolidation and reconsolidation by actin filament arrest in the basolateral amygdala. Neurobiol Learn Mem 94:117-126. CrossRef Medline

Rex CS, Gavin CF, Rubio MD, Kramar EA, Chen LY, Jia Y, Huganir RL, Muzyczka N, Gall CM, Miller CA, Lynch G, Rumbaugh G (2010) Myosin IIb regulates actin dynamics during synaptic plasticity and memory formation. Neuron 67:603-617. CrossRef Medline

Rodrigues SM, Schafe GE, LeDoux JE (2004) Molecular mechanisms underlying emotional learning and memory in the lateral amygdala. Neuron 44:75-91. CrossRef Medline

Rubio MD, Johnson R, Miller CA, Huganir RL, Rumbaugh G (2011) Regulation of synapse structure and function by distinct myosin II motors. J Neurosci 31:1448-1460. CrossRef Medline

Rust MB, Gurniak CB, Renner M, Vara H, Morando L, Görlich A, SassoèPognetto M, Banchaabouchi MA, Giustetto M, Triller A, Choquet D, Witke W (2010) Learning, AMPA receptor mobility and synaptic plasticity depend on n-cofilin-mediated actin dynamics. EMBO J 29: 1889-1902. CrossRef Medline

Schafe GE, Atkins CM, Swank MW, Bauer EP, Sweatt JD, LeDoux JE (2000) Activation of ERK/MAP kinase in the amygdala is required for memory consolidation of pavlovian fear conditioning. J Neurosci 20:8177-8187. Medline

Schratt GM, Tuebing F, Nigh EA, Kane CG, Sabatini ME, Kiebler M, Greenberg ME (2006) A brain-specific microRNA regulates dendritic spine development. Nature 439:283-289. CrossRef Medline

Siegel G, Obernosterer G, Fiore R, Oehmen M, Bicker S, Christensen M, Khudayberdiev S, Leuschner PF, Busch CJ, Kane C, Hübel K, Dekker F, Hedberg C, Rengarajan B, Drepper C, Waldmann H, Kauppinen S, Greenberg ME, Draguhn A, Rehmsmeier M, Martinez J, Schratt GM (2009) A functional screen implicates microRNA-138-dependent regulation of the depalmitoylation enzyme APT1 in dendritic spine morphogenesis. Nat Cell Biol 11:705-716. CrossRef Medline

Smalheiser NR, Lugli G (2009) microRNA regulation of synaptic plasticity. Neuromolecular Med 11:133-140. CrossRef Medline

Wang D, Huang J, Hu Z (2012) RNA helicase DDX5 regulates microRNA expression and contributes to cytoskeletal reorganization in basal breast cancer cells. Mol Cell Proteomics 11:M111.011932. CrossRef Medline

Wegner AM, Nebhan CA, Hu L, Majumdar D, Meier KM, Weaver AM, Webb DJ (2008) N-wasp and the arp2/3 complex are critical regulators of actin in the development of dendritic spines and synapses. J Biol Chem 283: 15912-15920. CrossRef Medline

Yu JY, Chung KH, Deo M, Thompson RC, Turner DL (2008) MicroRNA miR-124 regulates neurite outgrowth during neuronal differentiation. Exp Cell Res 314:2618-2633. CrossRef Medline

Zhang L, Liu T, Huang Y, Liu J (2011) microRNA-182 inhibits the proliferation and invasion of human lung adenocarcinoma cells through its effect on human cortical actin-associated protein. Int J Mol Med 28:381-388. CrossRef Medline

Zovoilis A, Agbemenyah HY, Agis-Balboa RC, Stilling RM, Edbauer D, Rao P, Farinelli L, Delalle I, Schmitt A, Falkai P, Bahari-Javan S, Burkhardt S, Sananbenesi F, Fischer A (2011) microRNA-34c is a novel target to treat dementias. EMBO J 30:4299-4308. CrossRef Medline 